\title{
Community Lifestyle and Religious Practices in Post Covid-19 Pandemic
}

\author{
Ahmad Zain Sarnoto ${ }^{1}$, Sri Tuti Rahmawati ${ }^{2}$, Rachmat Hidayat ${ }^{3}$ \\ \{ahmadzain@ptiq.ac.id ${ }^{1}$, sritutirahmawati@iiq.ac.id², rachmathidayat@uid.ac.id ${ }^{3}$ \} \\ Institut PTIQ Jakarta, Indonesia ${ }^{1}$, Institut Ilmu Al-Qur'an (IIQ), Jakarta, Indonesia ${ }^{2}$, \\ Universitas Islam Jakarta ${ }^{3}$
}

\begin{abstract}
The Covid-19 shocked the world upon its existence at the end of 2019. The virus which primarily attacks the respiratory tract, which can lead to death, was first discovered in the city of Wuhan Hubei, province in China. The Covid-19 pandemic outbreak has drastically changed human lifestyle across the world. Most noticeable amongst them is in the economic and livelihood activities, where people are now discouraged or even prohibited to congregate, while social distancing and wearing protective protective masks, effectively reducing economic activities. In addition to the economic impact caused by the virus on human activities, the virus also has an impact on religious rituals, Muslims must follow health protocols and carry out worship in their respective homes. This is the starting point for changes in Muslim religious activities. In fiqh literature, this form of leniency in worship is called rukshah, which literally means leniency or leniency. This study is about how people's lifestyles and religious practices must adapt due to the Covid-19 pandemic. The findings of this study can be a contribution of Islamic sociology which seeks to take a portrait of the condition of society in adapting to life during a pandemic and an analysis of the pattern of life of Islamic society after the Covid-19 pandemic.
\end{abstract}

Keywords: Lifestyle; Society; Community; Religion; Covid-19

\section{Introduction}

Muslims have reacted differently to the Covid-19 pandemic, particularly in Indonesia. Hasan Bisri used the case and experience of a small Muslim community in Ciamis, West Java, Indonesia, as an example. According to him, the Muslim response to the virus in Ciamis may be divided into five types. The five typologies are irrational-passive, which refers to those who hold beliefs that are not founded on scientific logic while also failing to offer solutions for Covid-19 prevention. Another group shows more character as active-haters but all of their arguments tend to be irrational. The third group shows a semi-rational character and supports government policies, the fourth group is rational but shy in presenting their arguments, and the fifth group they are rational-active-supportive[1].

Similar incidents occurred in other countries. Religious teachings are the root of Americans' adherence to government policies, as seen by their conduct. When this religious group politicizes the problem, however, they are more likely to disregard health protocols[2]. 
There are two sorts of people in American society: those who fall into the category of leftwing groups, and those who fall into the category of right-wing groups. This first group focuses on being more cautious. Second, those who are on the right (religious), who prefer to disregard medical and government recommendations. It is discovered that the right group's disregard for health norms is motivated by political alignments. They continue to enjoy eating out, seeing family/friends, gatherings of more than ten people, and without wearing masks or washing their hands. Such acts are founded on theological reasoning, such as the belief that Americans have a choice and are protected by God, therefore they do not accept news stories from the media. Christian nationalism differs from religiosity in that pure religion (with no political motivation) is the primary motivator for increased preventive efforts[3].

Religionist behavior exacerbates the loss of religious power and authority in the perception of the Indonesian people, as well as religiously connected medical experts, as authoritative sources in offering public prevention advice. Religious organizations and paramedics are also split. Religious groups and paramedics also disagree and are divided. According to Astra Zeneca, the procedure does not use pork. It was discovered through scientific investigations that LPPOM MUI occurs[5].

From various previous studies, the discussion on "how the community lifestyles and religious practices has had to adapt due to the Covid-19 pandemic" has not been widely studied. The most essential causes for the Muslim community's changes in religious practices and lifestyle patterns throughout the transition phase to health standards must be investigated. Religious rituals have altered dramatically during the pandemic compared to before the outbreak, yet for some groups, these activities are being preserved with their distinct discursive arguments. Similarly, the Muslim community's lifestyle has evolved by introducing new patterns, while some have persisted to the old ones.

\section{Methods}

This type of research is library research, where the data source is in the form of information about the public's response to health protocols during the pandemic which is obtained from library sources in the form of books, magazines, journals, newspapers, official state documents and internet sources. The approach used in this research is the sociology of religion, because although religion is individual, on the other hand, religion is also a social institution. In addition, religion is also a universal culture found in all social groups [6].

\section{Results and Discussion}

\subsection{Polarization of Society's Viewpoint}

Covid-19 pandemic outbreak in Indonesia for Muslims are forced to follow health protocols and follow the fatwa to carry out worship from their respective homes. This marked the beginning of a shift in Muslim religious practices[2]. This type of forbearance in worship is known as rukshah in fiqh literature, which literally means alleviation or mercy. The public, on the other hand, is still unfamiliar with the norms of Usul Fiqh al-masyaqqoh al-tajlibu altaisyiir, which state that an emergency provides convenience. The public is unfamiliar with the term "emergency," but it has a too restricted definition, which is confined to things that endanger life, such as a lack of food to support life. People's reactions differ when'fatwa institutions such as the Indonesian Ulama Council'(Majelis Ulama Indonesia/ MUI) issue 
regulations. Some people agree, while others disagree. Those who agree respond positively to MUI's efforts, while those who disagree publicly and privately refuse[7].

The principle of rukhshah applies not only to irregular workers and people, but also to medical staff who are in charge of public health. The problem that often arises and is experienced by the medical team is their use of personal protective equipment (PPE). As a result, the MUI issued Fatwa No. 17 of 2020. The MUI has a fatwa that the usage of PPE that does not enable medical professionals to conduct ablution correctly does not need to be removed, based on the religious concept of rukhsah. The medical team's law comes under the category of faqid al-tahurain in such a circumstance. Thus, medical personnel who wear PPE are allowed to perform prayers without ablution or tayammum [8].

The existence of a part of the public who rejects religious fatwas and government policies is not unreasonable. When MUI published Fatwa Number 14 of 2020, for example, popular opinion was diverse. Despite the fact that both sides' arguments are based on religious zeal, their actual outcomes are incompatible. If these disparities are investigated further, they are due to variances in requirements and other subjective variables that vary according to each person's personality[10].

Public rejection of religious fatwas and government policies is not without reason. If explored further, the causes of these differences are differences in needs and other subjective factors, depending on the contrast of each person's personality, the polarization of society cannot be separated from its environment. Their surroundings are high, and the religious instructors they follow come down to help establish a way of life and a mindset among the society [11]. As a result, the environment is the most powerful element affecting society's worldview in terms of adhering to government rules and authoritative ulama fatwas. However, if government laws exacerbate the environment, societal issues will worsen. The government's lack of clarity and indecisiveness in implementing health rules, as well as in enforcing fines on offenders, is one element that may be addressed here. All of this has a negative impact on the social environment.

\subsection{The Obscurity of Government Regulation}

According to experts, the problem with the Indonesian government stems from a legal issue that has yet to be resolved. Despite the fact that Covid-19 is an infectious illness with the potential to cause a public health emergency, preventative actions against this type of infectious disease are not taken as soon as feasible. In Indonesia, there is currently no legislation or regulation governing the prevention of infectious illnesses. According to Dalinama Telaumbanua, there are five (5) government rules and eleven (11) necessary health ministry regulations must be adopted in order to combat and avoid the threat of the Covid-19 infectious illness[12].

At the beginning, President Joko Widodo committed a mistake from March 2, 2020, when he declared the first (and second) positive case of the new coronavirus, or Covid-19 illness, in Indonesia. Before the health staff notified the patients personally, the president made an announcement to the public. This episode became one of several major blunders made by the administration, which created severe doubts about the government's ability to respond to the worldwide epidemic. Although the primary focus must be on treating individuals who are already sick and avoiding further spread, a thorough investigation must also be conducted at the appropriate time[14].

\subsection{Religious Rationalization and Delegitimization of The State}


The criticism of the mosque's closure came not only from the general public, scientists, and religious leaders, but also from politicians. Yandri Susanto, Chairman of House of Representatives Commission VIII, expressed his opposition to the government's plan to shut mosques and other houses of worship. There will be no forced disbandment or closing of houses of worship during this Emergency PPKM, according to PAN's Deputy Chairperson. Mosques and other houses of worship, he claims, may continue to function while adhering to health regulations. Mosques, according to Yandri, can stay open if rigorous health standards are implemented [19].

A government and a state become delegitimized in the minds of the public if a series of national and state problems cannot be resolved in the shortest possible time[20]. In other words, if the Indonesian people's religious patterns continue to conflict with health standards throughout the pandemic, the state will lose legitimacy in the eyes of its population. Alternatively, the state is delegitimized when the implementation of a law no longer fulfills the principle of justice values set by the state through its law enforcement agents, causing people to demand the value of justice [21]. As a consequence, religious rationalization among Indonesians can act as a catalyst for efforts to delegitimize the state, particularly when religious enthusiasm is supported by every segment of society, from the grassroots class to the elite, from lawyers to religionists and politicians.

\section{Conclusion}

During the Covid-19 pandemic, the Indonesian Muslim community's lifestyle began to shift, one of which may be observed is their religious rituals. Religious organizations and certain religious figures have issued fatwas in support of government programs to control and prevent the spread of the Covid-19. However, polarization develops within society, resulting in the emergence of a new sociological category known as pro-government, which tends to oppose the majority.

On the one hand, this polarization weakens political authority, while on the other it reflects the disintegration of society, which often leads to violence. As a result, the religious practices and lifestyles of the Indonesian people became inconsistent, and remain so to this day.

\section{References}

[1] H. Husni, H. Bisri, T. A. Tantowie, S. S. Rizal, and A. Azis, "Religious community responses to COVID-19: case study on Muslim small community," Int. J. PsychosociaI Rehabil., vol. 24, no. 8, pp. 10439-10446, 2020.

[2] A. Z. Sarnoto and L. Hayatina, "Polarization of the Muslim Community Towards Government Policies in Overcoming the COVID- 19 Pandemic in Indonesia," Linguist. Cult. Rev., vol. 5, no. July, pp. 642-652, 2021, doi: https://doi.org/10.37028/lingcure.v5nS1.1449.

[3] S. L. Perry, A. L. Whitehead, and J. B. Grubbs, "Culture Wars and COVID-19 Conduct: Christian Nationalism, Religiosity, and Americans' Behavior During the Coronavirus Pandemic," J. Sci. Study Relig., vol. 59, no. 3, pp. 405-416, 2020, doi: 10.1111 jssr.12677.

[4] A. Faizal, "PWNU Jatim: Vaksin AstraZeneca Suci dan Halal kendati Terdapat Unsur Babi Saat Pembuatannya," March 22, 2021. https://regional.kompas.com/ (accessed August 5, 2021)., 2021.

[5] MUI, “Apa Status Kehalalan Vaksin Pfizer dan Moderna?,” dalam https://mui.or.id/, 
25 Agustus 2021, 2021.

[6] L. L. Richardson, Introduction To Library Research In German Studies: Language, Literature, And Civilization. New York : Routledge, 2018.

[7] Sahari, "Implementasi Al-Masyaqqoh Al-Tajlibu Al-Taisyiir Di Tengah Pandemi Covid-19," J. AQLAM - J. Islam Plur. -Volume 5, Nomor 2, Desember 2020 IMPLEMENTASI, vol. 5, no. 2, pp. 139-151, 2020.

[8] C. R. M. Amel, "Konsep Rukhsah Bagi Tenaga Medis Dengan Alat Pelindung Diri Saat Menangani Pasien COVID-19," Al-Qanun J. Pemikir. Dan Pembaharuan Huk. Islam, vol. 23, no. 1, pp. 1-21, 2020.

[9] Syamsuddin, "Keringanan (Rukhshah) Meniadakan Shalat Jumat dan Shalat Jama'ah serta Kewajiban Menaati Ulul Amri Syamsuddin," Al-"adl, vol. 13, no. 2, pp. 165184, 2020.

[10] M. F. Imaduddin, "Studi Persepsi Masyarakat Terhadap Fatwa Mui No. 14 Tahun 2020 Tentang Penyelenggaraan Ibadah Dalam Situasi Wabah Covid-19," JISA J. Ilm. Sosioologi Agama, vol. 3, no. 2, pp. 92-113, 2020.

[11] A. Z. Sarnoto and S. Romli, "Pengaruh Kecerdasan Emosional (EQ) Dan Lingkungan Belajar Terhadap Motivasi Belajar Siswa Sma Negeri 3 Tangerang Selatan," Andragogi J. Pendidik. Islam dan Manaj. Pendidik. Islam, vol. 1, no. 1, pp. 55-75, 2019, doi: 10.36671/andragogi.v1i1.48.

[12] D. Telaumbanua, "Urgensi Pembentukan Aturan Terkait Pencegahan Covid-19 di Indonesia," QALAMUNA J. Pendidikan, Sos. dan Agama, vol. 12, no. 01, pp. 59-70, 2020, doi: 10.37680/qalamuna.v12i01.290.

[13] L. Agustino, "Analysis Of Covid-19 Outbreak Handling Policy: The Experience Of Indonesia," J. Borneo Adm., vol. 16, no. 2, pp. 253-270, 2020, doi: 10.24258/jba.v16i2.685.

[14] A. I. Almuttaqi, "The omnishambles of COVID-19 response in Indonesia," THC Insigjts, vol. 1, no. 13, pp. 1-7, 2020.

[15] RadarTegal, "Tolak Masjid Ditutup Selama PPKM Darurat, UAS Disentil Eko Kuntadhi: Gak Malu Sama Ratusan Ribu Orang yang Kehilangan Keluarganya? Juli 3, 2021," https://radartegal.com/ (accessed Agustus 7, 2021), 2021.

[16] MetroTV, "MUI Sumbar Tolak Penutupan Masjid di Zona Merah, Ini Respon Cholil Nafis. Juli 9, 2021," https://www.metrotvnews.com/ (accessed Agustus 7, 2021), 2021.

[17] WartaEkonomi, "Seperti Ustad Somad, Tokoh NU Semprot Ulama yang Protes Masjid Ditutup, Pedes Bos: Makanya Mikir! Juli 8, 2021," https://www.wartaekonomi.co.id/ (accessed Agustus 7, 2021), 2021.

[18] CNNIndonesia, "Ketua MUI Usul Masjid Tak Ditutup Total Saat PPKM Darurat. Juli 2, 2021," https://www.cnnindonesia.com/ (accessed Agustus 7, 2021), 2021.

[19] Kiswondari, "Kritisi Aturan PPKM Darurat, Yandri Susanto: Kenapa Masjid Ditutup Sementara Kantor dan Pasar Masih Boleh Buka? Juli 2, 2021," https://nasional.sindonews.com/ (accessed Agustus 7, 2021)., 2021.

[20] S. Gautama, Megawati Soekarnoputri, Harapan dan Tantangan di Kursi Wapres R.I. Yogyakarta: Rineka Cipta, 2000.

[21] S. Arief, "Penegakan Hukum dan Delegitimasi Negara. Juli 16, 2007. https://www.hukumonline.com/ (accessed Agustus 7, 2021),” 2007. 